\title{
The Maritime Policy of the Tyrants of Pherae
}

\author{
Sławomir Sprawski \\ iD http:/orcid.org/0000-0002-6904-5544 \\ Jagiellonian University in Kraków
}

\begin{abstract}
This article examines the role played by the sea in the policy of the tyrants of Pherae. Although it has often been emphasised that control over the port in Pagasae and the profits from the maritime trade were closely linked to the city's increasing importance in the late 5th and first half of the 4th century, these issues are yet to be the subject of a more detailed analysis. This article is the first part of a comprehensive study on the maritime activity of the Pheraean tyrants in the period from Jason's first documented political move to the end of the reigns of Lycophron and Peitholaus. It focuses on political moves, and especially on relations with Athens, as the largest maritime power of the period. One of the most important instruments of maritime policy was maintaining a fleet. The article considers the circumstances of its building, its size and its use.
\end{abstract}

Key words: Jason of Pherae, tyrants of Pherae, maritime policy of the tyrants of Pherae, Beotia, Thessaly, Athens, Thebes, fleet, 4th century BCE.

For more than 50 years from the close of the 5th century, the rulers of Pherae with the aid of mercenary armies attempted to bring the whole of Thessaly under their rule. ${ }^{1}$ One of the results of these actions was that their country became involved in the political rivalry waged between Sparta, Athens, Thebes and the Macedonian kings. An explanation for why Pherae ended up supporting such ambitious and expensive activities is its links to the sea. H. D. Westlake, author of the classic study of the history of Thessaly in the 4th century BCE, noted that Pherae's proximity to the sea and control of the port in Pagasae "was to a large extent responsible for the swift rise of Pheraean power towards the close of the 5th century." Loss of this control meant the fall of the tyranny. ${ }^{2}$ Pagasae, Thessaly's only true port and described by Theopompus as epineion Pherai, must have

1 In this article, I use the terms "the tyrants of Pherae" or "Pheraean tyrants," which express their ambitions to gain rule over the whole of Thessaly. There is no doubt that they also ruled over Pherae, but we know almost nothing about the nature of this. On this subject, see Sprawski 2004. The paper was completed thanks to financial support from the Polish National Science Centre (grant: UMO-2012/07/B/HS3/03455).

2 Westlake 1935, 10-11. 
been the source of the city's major income. Pagasae had links with the family of the Pheraean tyrants, especially Alexander, who was even the subject of a heroic cult after his death. ${ }^{3}$ Although Pherae's connections with the sea have been addressed on many occasions, the question of the role it played in the tyrants' policy has not been the subject of a separate study. In this article, I will attempt to answer this question by focusing on two major issues. The first is evidence referring to the existence and operation of the Pheraean fleet, known mainly because of Alexander's pirate attacks on the Cyclades. The second is the relations with Athens, the largest maritime power of the period, as well as the rival Thebes. The chronological framework for this discussion is marked by the start of Jason's rule (c. 380 BCE) at the beginning and the removal of his sons Lycophron and Peitholaus from Pherae (353 BCE) at the end.

\section{Jason's Great Plans}

The oldest source on the Pheraean tyrants is a mention of a battle waged by Lycophron in 404 in the hope of gaining power over the whole of Thessaly. None of the other few references to it mentions maritime policy. ${ }^{4}$ Out of necessity, therefore, we must begin our analysis with the brief mention demonstrating Jason's involvement on Euboea. This was also his first documented political move. According to Diodorus, a certain Neogenes, with the help of Jason of Pherae, assembled soldiers and occupied the citadel of the city of Histiaea, before taking tyrannical power over the city and the entire country. ${ }^{5}$ We do not know any other details of Jason's participation in these events, and we cannot exclude the possibility that the help he provided might have been largely confined to financial support for the venture. We can only guess at the reasons for this involvement. The most obvious one appears to be the location of the city of Histiaea near a strait leading to the Euboean Channel, through which there led a safe communications route from north to south. As a result, sailors could avoid the eastern coast of Euboea, which was known to be dangerous and for its capricious weather. Those who choose that route had to expect a high risk of disaster. This was the location of the famous Koila, where the Persian fleet was destroyed in 480, as well as the headland of Kaphareus, where, according to mythical tradition, the Achaean fleet were shipwrecked. Sailors also faced major obstacles in the straits between Euboea and Andros as well as Andros and Tenos. Strong sea currents combined with strong northern winds could block the passage completely. It is therefore not surprising that the route through the safe Euboean Channel was also preferred by sailors setting off on the long voyage from Athens towards Pontus. ${ }^{6}$ A crew stationed in Histiaea could also effectively block the trade route leading south from $\mathrm{Pa}$ gasae, Thessaly's main port. This was probably the objective of the Spartans, after overthrowing Neogenes' tyranny, when they installed a harmost with a small squadron comprising three triremes there. According to Xenophon, in 377 Alketas was able to block

\footnotetext{
3 See Boehm 2015, 209-251.

4 Xenoph. Hell. 2.3.4. On Lycophron, see Sprawski 1999, 38-48.

5 Diod. 15.30.3.

6 Hdt. 8.13; Eurip. Helen 766-67; Constantakopoulou 2007, 25, 130; Bresson 2016, 368-369.
} 
a transport of grain bought by the Thebans in Pagasae. To gain an influence on shipping on this route, Jason might have exploited the internal tensions in Histiaea and tried to insert one of his trusted men there. He thereby joined the competition for the best places that was taking place in the Aegean world of the 4th century BCE between both stronger and weaker players. Even the inhabitants of little Peparethos took advantage of favourable conditions to attack the even weaker island of Halonessos. ${ }^{7}$

When writing about Jason's maritime policy, we cannot fail to mention his plans presented by Xenophon in Hellenica. These take the form of Jason's words quoted in a speech to the Spartans given by Polydamas, the leader of the Thessalian city of Pharsalos. It is therefore hard to determine the extent to which the opinions presented in it reflected Jason's true views and plans. Analysis suggests that Xenophon was trying to portray Jason as an example of an ambitious ruler and good commander, who had the chance to do great deeds, but was defeated, murdered by assassins. He also presents him as a person capable of using extremely convincing arguments based on cool and logical analysis of the situation, and as a politician making bold and far-reaching plans. ${ }^{8}$ When courting Polydamas' cooperation, Jason presents him with a vision of the greatness the Thessalians could acquire, united under the leadership of a well-chosen tagus. His plans mainly concerned building a land power that could successfully challenge the Spartan hegemony in Greece. Jason presents a simple alternative: the Thessalians could either be a hypekooi, a people that submitted to foreign leadership, or they could themselves lead and possess their own hypekooi. He assures Polydamas that after uniting Thessaly under his leadership, all the current opponents of the Spartans would seek to form an alliance with him. This would also apply to the Athenians:

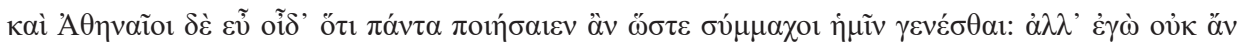

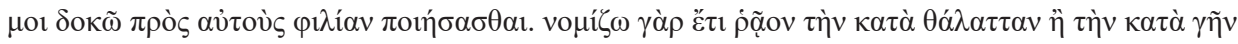

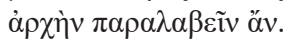

The Athenians also, I know very well, would do anything to become allies of ours, but I do not think it best to establish a friendship with them; for I believe that I could obtain empire by sea even more easily than by land. ${ }^{9}$

In the context of potential collaboration with the Athenians, Jason spoke about do-

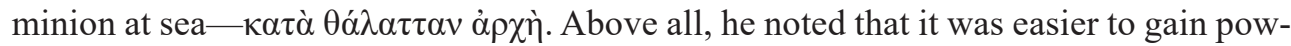
er at sea than on the land. Secondly, after assuming power in Thessaly, he would have greater resources than the Athenians to build and maintain warships. Jason also showed that by controlling Macedonia he would have easier access to sources of the wood which the Athenians used to build their ships, and would therefore be able to build more than them. He then compared the potential of the two sides, showing that the Thessalians would find it much easier to assemble and maintain a large fleet than the Athenians, since the penestae could offer an easy source of recruits for forming the warships' crews. These crews could easily be maintained thanks to surpluses in crop production, which, as he noted, the Athenians were forced to import. Finally, he mentioned that he

7 Xen. Hell. 5.4.56 (Histiaea); [Dem.] 12.15 (Halonessos). See Brun 1993, 177-190; Rutishauser 2012, 154-155; Duszyński 2016, 67-68.

8 Xen. Hell. 6.1.4-16; Wilcken 1924, 127; Sordi 1958, 176-177; Cartledge 1989, 378.

9 Xen. Hell. 6.1 .10 (tr. C. L. Brownson). 
had more money than the Athenians because he reaped the benefits from the peoples

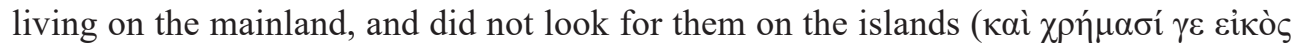

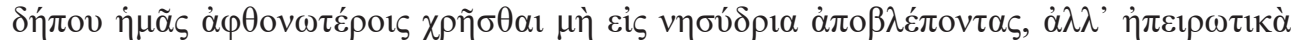

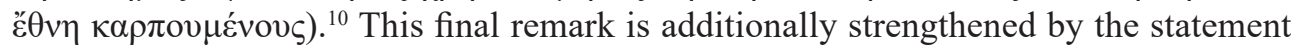
that the Persian king, the richest of all men, also profited from ruling on the mainland and not islands. This is also an introduction to Jason's conclusion, which is the statement that the power he was building would suffice to lay down a challenge to the Persian king. According to the tyrant, overcoming the Great King was an easier exercise than imposing dominion over Greece.

The words that Xenophon puts in Jason's mouth give the impression of a very cool and rational assessment of the conditions essential for gaining and maintaining hegemony at sea. This analysis is the basis for evaluating the actual power held by the strongest states of his time- - Sparta, Athens and Persia. Jason showed that he was able to assemble sufficient allies to face up to Sparta. Making use of the resources of Thessaly and Macedonia, with whose king he joined forces, he had no trouble raising a fleet exceeding Athens' maritime force. With this power at his disposal, he was able to successfully challenge the Persian Empire. These final statements sound so audacious that it is hard to resist the impression that Xenophon wanted to emphasise the hybris of Jason, who had no end to his ambitions. This observation seems to be confirmed by Xenophon's words contained in the second excurse on Jason, in which he presents the development of events after the Battle of Leuctra, when he reached the peak of his power and began to accomplish his plans for hegemony. The historian mentions that his killers were greeted with joy in Greek cities that feared Jason would become a tyrant. Death at the hands of assassins might seem to be a sudden turn of fate and appropriate punishment for an overambitious man who aspired to power on land and sea and hatched plans to subject the whole of Greece and even the Persian king to his rule. ${ }^{11}$

Although Jason's plans presented by Xenophon seem excessively ambitious, it is important to note that in unfolding his vision of the future might of Thessaly he did not state outright that his objective is to gain power at sea. He simply noted that this was an easier task than gaining dominion on the land. His comments might be more theoretical than real in nature. It is also worth paying attention to his words on the weakness of the islands. These coincide with the statements of many Athenian authors from the turn of the 4th century BCE, and do not necessarily result from his own reflections. ${ }^{12}$

Without doubt, towards the end of his life Jason possessed a fleet capable of offensive manoeuvres. We hear about it in the context of the events of the year 371 after the Battle of Leuctra, when the Thebans, preparing for an attack on the Spartans, enclosed in their camp, sent delegations to Athens and Jason with a request for help. Jason responded positively to the call from his allies, deciding on a quick march to Boeotia with a unit of mercenaries and cavalry. At the same time, writes Xenophon, he manned triremes (cvi $\theta \dot{v} \varsigma$

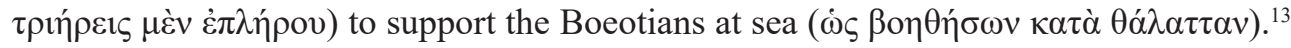

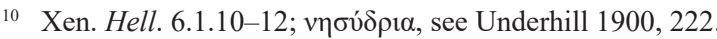

1 Xen. Hell. 6.4.27-32; Westlake 1935, 100-101; Grey 1989, 163-165.

2 See Isocr. 4.132, 136; 8.118; Brun 1993, 165-183.

3 Xen. Hell. 6.4.21. 
We find no information in the sources on the number of warships Jason possessed in 371 and their date of construction. It seems unlikely that he could have rebuilt his fleet during the King's Peace. Its conditions are thought to have included a clause ordering the dissolution of the fleet. This is suggested by a reference to such a clause in the treaty from 371 that renewed the previous pact. ${ }^{14}$ It is hard to imagine that Jason would have dared to so flagrantly violate the conditions of the treaty by developing his armada. More likely is the possibility that he did this only after the outbreak of the Boeotian War in 378. This interpretation is supported by Polydamas' speech in Xenophon's Hellenica, in which, describing Jason's might in 375, he says nothing about his fleet. He only mentions that Jason was ready to expand his forces using wood imported from Macedonia as well as the penestae, among whom he planned to recruit crews. Therefore, if he indeed implemented a project of building of warships, he could only have done this after bringing the whole of Thessaly under his control, which must have happened in late 375 or early 374 . According to Xenophon, after being elected tagus he set about rebuilding his military powers. Diodorus also places Jason's alliance with the Macedonian king Amyntas in the course of events commenced by the Thessalians entrusting him with command over all the forces. ${ }^{15}$ It may have been this alliance that provided him with access to the raw materials needed for building warships. It therefore seems that the most likely time when he could have expanded his fleet was 373-371.

The time when Jason might have developed his fleet overlaps with the period when he pursued closer political relations with Athens. According to Xenophon, in 375 Polydamas assured the Spartans that Jason had been critical about the possibility of forming an alliance with them. Yet in autumn 373 Jason appeared in person in Athens to testify together with Alketas, king of Epirus, in a trial on behalf of the Athenian commander Timotheus. At this time, according to Apollodorus, both rulers were allies of the Athe-

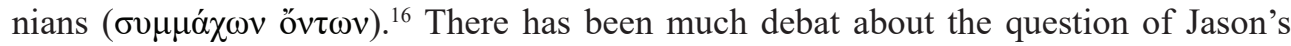
belonging to the Second Athenian League, beginning in the late 19th century with a proposal to reconstruct his name in the place of a rasura on a list of the states that joined the alliance. Epigraphically, we cannot entirely rule out the legitimacy of such a reconstruction. But in what respect would Jason appear in the league - as a tyrant of Pherae or as tagus of the Thessalians? Given Jason's great efforts to legitimise his position with his election as tagus, it seems doubtful that this name should appear on the stele, and not the name Thessalians. For the same reason, it seems even less likely that he would have appeared in the name of Pherae, thereby underlining his tyrannical rule in the city. If he led Pherae to join the alliance, then it should be the name of the Pheraeans that appears on the stele, as F. W. Mitchell has proposed. A solution to this problem may also lie in adopting J. Cargill's suggestion that Jason never joined the Second Athenian League, but formed a bilateral alliance with the Athenians. ${ }^{17}$ Accepting this solution allows us

14 Xen. Hell. 6.3.18.

15 Xen. Hell. 6.1.11; Diod. 15.60.2. Diodorus incorrectly places the assumption of rule over Thessaly, subjugation of the local peoples and alliance with Amyntas after the Battle of Leuctra, see Sprawski 1999, 79-80.

16 Xen. Hell. 6.1.10; [Dem.] 49.10; Nepos Timoth. 4.2-3.

17 IG II ${ }^{2}$ 43, l. 111= R\&O 22, l. 111; Cargill 1981, 83-89; Mitchell 1984, 50-58. For earlier discussion, see Sprawski 1999, 82-93; Buckler 2003, 252. 
to bypass the problem of looking for his name on the aforementioned stele, although it leaves the unanswered question of whose name this alliance was formed in. The problem is significant as we find no other confirmation that the Athenians were united by an alliance with the Thessalians or Pheraeans before they allied with Alexander of Pherae, as shall be discussed below.

Although it is not easy to define the nature of the ties connecting Jason with Athens, there is no doubt that his relations with Timotheus were so strong that he decided to travel to attend his trial. They may have become close on the occasion of Timotheus' warfare on the Ionian Sea in 375. As a result, the general occupied Korkyra and was victorious over the Spartan fleet in the Battle of Alyzia. Many states of Western GreeceKorkyra, Kephalenia and Akarnania-followed his example and joined the alliance with the Athenians. After an unsuccessful attempt at renewed peace in 373, the Athenians sent a unit by land westward under the command of Ktesikles to recommence the war. They obtained the agreement of Alketas, ruler of the Molossians, to pass through their territory, as well as help in crossing over to Korkyra. It may have been during these battles that Alketas joined the Second Athenian League. Given his links with Jason, it is probable that the Thessalian tyrant was involved in these events. Although the sources contain no information on this subject, there is conjecture that before arriving in Epirus, Ktesikles' unit marched through the territories controlled by Jason. It is notable that Jason and Alketas retained close ties with Timotheus, who at this time was placed in charge of a fleet setting sail to help Korkyra. But before he could depart for the West, he was forced to sail around the Aegean Sea to man his warships and collect money to fund the campaign. The delay caused concern and dissatisfaction among the Athenians, who stripped him of command and put him on trial, which took place in late $373 .{ }^{18}$

The fact that Jason travelled to Athens in person to testify on Timotheus' behalf suggests that supporting his career was important to him. Moreover, we know that Jason furthered his relations with the Thebans by seeking personal contacts with their eminent citizens Pelopidas and Epaminondas. ${ }^{19}$ He may have exploited the institution of ritualised friendship in a similar way to maintain ties with Timotheus. It is interesting that the description of Jason's arrival at the home of the Athenian politician gives the impression of a very informal visit. The unprepared host had to hurriedly borrow sheets, coats, two silver bowls and money from the banker Pasion in order to accommodate his guests. ${ }^{20}$ Jason appeared in Athens as somebody who did not have to prepare his visit ahead of time, yet still felt safe in the city. He no doubt expected the Athenians to be welcoming. His words quoted by Xenophon and cited above on the Athenians' readiness to form an alliance also betray a similar confidence that they were sympathetic towards him

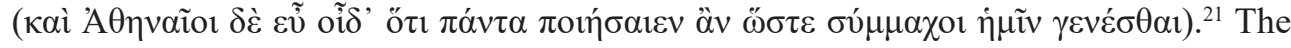
question arises here whether we can rule out that Apollodorus was mistaken in writing that during Timotheus' trial Jason was an ally of Athens. We know from his words that Alketas was also one, and Apollodorus always mentions his name first. In Alketas' case, however, we have evidence confirming his alliance with Athens. His name is found on

18 Xen. Hell. 6.2.9-13; Diod. 15.46.3, 47.2-3; Buckler 2003, 264-265.

19 Plut. Pelop. 28.3-4; Mor. 193 B, 583 F; Aelian, VH 11.9.

20 [Dem.] 49.22-24.

21 Xen. Hell. 6.1.10. 
the stele among other allies, and Xenophon confirms his support for Ktesikles' detachments. In Jason's case, there were no such testimonies. Apollodorus may have made an error because although Jason was not bound by a formal alliance, he was seen as a friend of the Athenians. Mindful of this situation, Xenophon quotes his real or supposed words explaining what plans stopped him from making a formal alliance.

We know more about the formal relations between Jason and the Boeotians. According to Polydamas' speech, the Boeotians and others fighting with the Spartans were

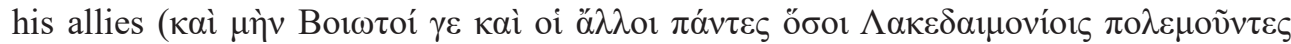

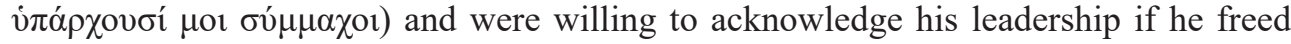
them from Spartan domination. The alliance must still have been in operation during the Battle of Leuctra. Xenophon mentions that he was an ally of the Thebans when they

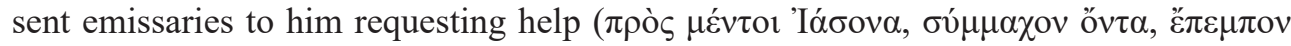

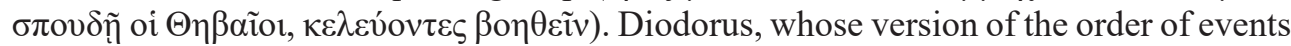
is different, writes of the arrival of an allied contingent of Thessalians. Unlike in the case of Athens, here we have testified rapid military aid for an ally. Jason sent an equestrian unit, his mercenaries and triremes to Leuctra. ${ }^{22}$

The Boeotian campaign is the first confirmed evidence of use of the Pheraean fleet. It is unclear, however, what tasks it was supposed to carry out. Leuctra is in the southern part of Boeotia, nearer to the Gulf of Corinth. The Pheraean fleet could therefore provide support for the units marching to the battlefield only during their passage through Thermopylae. We hear nothing about Sparta's maritime forces being active in the Euboean Channel in 371, so they were probably not a potential opponent. There has also been various conjecture on this issue. Some people have suggested that the purpose of the fleet might have been to ensure the neutrality of Athens, which was very lukewarm in its reaction to news of the Thebans' victory at Leuctra and refused them support in further battles with Sparta. Others have pointed to the desire to mislead the Phocians, who were hostile to the Thessalians. This is because Xenophon writes that Jason manned his tri-

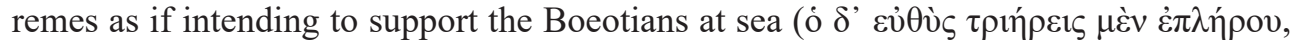

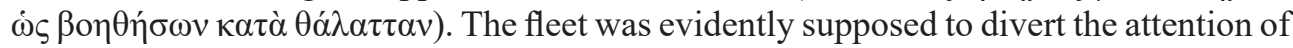
the Phocians, allowing him to pass quickly through their territory before they managed to react. ${ }^{23}$

A hint regarding the maritime objectives of Jason's activities might be provided by his conduct during the time of the entire Boeotian campaign. On the way to Leuctra, he moved fast, forestalling the reaction of potential enemies. Despite reporting in person with his unit at Leuctra, he did not intend to join the battle, but brought about a truce. On his return journey to Thessaly, Jason conducted one more action that might have been connected to his activities at sea-he destroyed Heraclea in Trachis, which lay close to the northern entrance to Thermopylae. According to Xenophon, he did this so that nobody would be able to stop him if he intended to head to southern Greece. ${ }^{24}$ Thucydides also notes another aspect of the strategic location of this city. Describing the circumstances of its situation, he emphasises that the Spartans chose this place not

22 Xen. Hell. 6.4.20-22; Diod. 15.54.5.

23 Westlake 1935, 92; Mandel 1980, 69; Mitchell 1984, 54; Tuplin 1993, 118; Sprawski 1999, 96, note 240 .

24 Xen. Hell. 6.4.27. 
only because it lay on the road to Thrace, but because it was easy to prepare a fleet for an attack on nearby Euboea from there. ${ }^{25}$ The Spartans therefore also had the intention to set up a base for their fleet close by when they established Heraclea. When making his claims to rule over the sea communications route along the western coast of Euboea, Jason took the opportunity to destroy a foothold for potential rivals.

Jason's warships sailing in the Malian Gulf must have been highly visible for many local inhabitants. They were a clear signal that Jason possessed the necessary forces and was determined to play the role of hegemon in the region. ${ }^{26}$

\section{Alexander between Thebes and Athens}

Jason's death in 370 destabilised the political situation in Thessaly, opening the next chapter of domestic rivalry and foreign interventions. Both Jason's successors and the Thessalian cities relying on them were searching for outside support. In the $360 \mathrm{~s}$, both the Thebans and the Athenians, who in 369 finally became fierce rivals, were willing to offer such support. The Athenians redirected their policy significantly, forming an alliance with Sparta, hitherto their main rival, against Thebes. At the same time, probably still in 369, they commenced military efforts to regain Amphipolis, sending a fleet under the command of Iphikrates to the North. ${ }^{27}$ This was a time when the Second Athenian League was weakened, as several states followed Thebes in leaving it. Yet the alliance survived, as its existence delivered many tangible benefits. The Athenian fleet patrolling the Aegean Sea had a major influence on guaranteeing the safety of ships, contending with pirates and aiding the development of maritime trade. ${ }^{28}$

The rivalry between Athens and Thebes also affected the North, which was reflected in a sequence of short-lived alliances formed by these states with rival factions among both the Thessalians and the Macedonians. In Thessaly's case, source information is limited, and it is therefore hard to build a logical and coherent picture of the evolution of these relations. It sometimes seems that almost every year brought a change, which makes it difficult to determine whether the parties were allied at a given moment, or their ties had been broken. The conclusion is, therefore, that this surprising fragilty and ineffectiveness of these alliances resulted not only from the complicated internal situation, but also to a great extent from the inconsistent policy of Athens and Thebes, for which this was not the most important area of activity. ${ }^{29}$

After Jason's death, his brothers Polydorus and Polyphron took power in Thessaly without great difficulty. Soon after, Polydorus was killed by his brother, who assumed full power. It was presumably to him that the summons arrived from Thebes to join an expedition against Sparta. According to Xenophon, in winter 370/369, when Epaminondas set off for the Peloponnese, he was supported by the Phocians, Euboeans from

25 Thuc. 3.92.4.

26 Xen. Hell. 6.4.27. Cf. Larsen 1960, 231-234; Tuplin 1993, 119, note 50.

27 Aesch. 2.27; Buckler 2003, 354-355.

28 Cawkwell 1981, 47-48.

29 See Cloché 1935, 123; Kallet 1983, 242-243. 
all cities, Locrians, Heracleans and Malians. Cavalry and light infantry from Thessaly also participated in the expedition..$^{30}$ This might indicate that Polyphron preserved the alliance with the Thebans formed by Jason. Westlake points out that the way Xenophon mentions the Thessalian forces at Epaminondas' side shows that they might not have been units of the Thessalian League, but rather mercenaries. ${ }^{31}$ It seems likely that they may have been detachments formed by Jason, who came under Polyphron's pay after Jason's death. By confirming the alliance with the Thebans, Polyphron also strengthened his position in the land. During his brief reign, he had Polydamas and eight of the most influential citizens of Pharsalos murdered. Xenophon presents these events as an example of the transformation of the rule of tagus into tyranny. ${ }^{32}$ The fact that Polydamas had previously declared himself as a Spartan ally might have led to doubts over his loyalty and resulted in the need to deal with him. ${ }^{33}$

In summer 369, Polyphron was murdered by his nephew Alexander, who assumed power in Pherae and the rank of tagus. ${ }^{34}$ His actions met with immediate opposition from some Thessalians. The Larisseans called upon Alexander II of Macedon for help, and he responded with a surprise incursion to Thessaly, setting up garrisons in Larissa and Crannon. ${ }^{35}$ Also called upon to intervene were the Thebans, who, according to Diodorus, were asked to liberate the Thessalians from Alexander's tyranny. ${ }^{36}$ The Theban forces invaded Thessaly, led by Pelopidas. He negotiated the Macedonians' withdrawal from the occupied cities, as well as mediating between Alexander and his opponents. According to Plutarch, who had a hostile attitude towards Alexander, Pelopidas "tried to make him, instead of a tyrant, one who could govern the Thessalians mildly and ac-

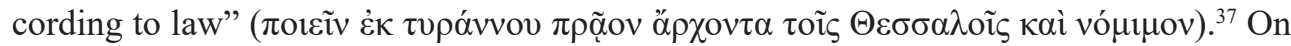
this basis, we can assume that his objective was not to remove Alexander, but only to alleviate the conflict in Thessaly. It was possibly then that the Thessalian koinon was reorganised, proposing Alexander a new position instead of the rank of tagus. Alexander broke off the negotiations as he was unhappy with their progress, which in practice entailed open conflict with Thebes. Yet he was unprepared for this, and after few battles decided to make a compromise. The situation in Thessaly was under control to the extent that Pelopidas was able to set off to Macedonia, where he supported Alexander II against his rival Ptolemy, forming an alliance with him. After dealing with affairs in Thessaly and Macedonia, he returned to Boeotia. ${ }^{38}$

Unsuccessful in gaining the support of Thebes in 369, Alexander of Pherae was forced to look for another ally. The only choice was the Athenians, who at this time had revived their policy towards the North. In spring 368 their interest in the situation in Thessaly was so great that they wanted to send mercenaries dispatched by Dionysius,

30 Xen. Hell. 6.5.23. Diodorus (15.62.4) mentions only the Locrians and Phocians.

1 Westlake 1935, 128-129.

Xen. Hell. 6.4.34.

Xen. Hell. 6.1.4.

Xen. Hell. 6.4.34-35.

Diod. 15.61.2-5.

Diod. 15.67.3. See Westlake 1935, 132-133.

Plut. Pelop. 26 (tr. B. Perrin).

38 Buckler 2003, 321-323. 
tyrant of Syracuse, there. These units were to support the coalition partners fighting with the Boeotians, who ultimately acceded to the judgement of the Spartans to use them in the Peloponnese. Suggesting sending mercenaries to Thessaly, the Athenians wanted to direct them against the Thebans. ${ }^{39}$ The Thebans, called upon by the Thessalian cities threatened by Alexander, accepted the invitation to intervene. But they did not regard the situation as sufficiently serious to engage armed forces, deciding instead to send only a delegation in the guise of Pelopidas and Ismenias to mitigate the conflict. We do not know the outcome of their talks, but Pelopidas felt sufficiently confident in Thessaly that he undertook a further intervention in Macedonia against Ptolemy, the regent after Alexander II's death. Somewhat earlier, Iphikrates intervened in Macedonia, supporting Ptolemy and bringing about an alliance with Athens. Pelopidas dealt with matters in Macedonia in keeping with the Thebans' ideas, encouraging Ptolemy to form an alliance. He then returned to Thessaly, where, together with Ismenias, he was unexpectedly imprisoned by Alexander of Pherae. ${ }^{40}$

There is much to suggest that Alexander had a very impetuous nature and did not hesitate to take risky steps. ${ }^{41}$ One of these was the arrest of Pelopidas and Ismenias, which incurred the wrath of the Thebans and exposed him to another armed intervention on their part. Yet this was not necessarily the move of a desperado failing to reckon with realities. As mentioned above, Alexander had reasons to be profoundly disappointed with Pelopidas' attitude. Despite the ties that had once connected the Theban with Jason, he was now no longer inclined to offer his nephew unequivocal support. Owing to Pelopidas' position, the only worthwhile force that Alexander could enlist for himself was the Athenians. Their efforts to send to Thessaly mercenaries dispatched with aid for the anti-Theban coalition by the Syracusan tyrant Dionysius demonstrated their interest in the situation in the region. At this time, they were still not fully on Alexander's side, since they had only formed an alliance with him in the second half of 368. A hint of the Athenians' objectives is given by Xenophon, who writes that in requesting that the mercenaries sent by Dionysius be dispatched to Thessaly, they argued that they should be

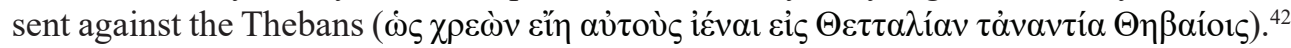
We can therefore assume that their main objective was rather preventing the Theban influences in Thessaly from becoming stronger, rather than unequivocal support of Pherae. Alexander's manoeuvre was therefore risky, but rational. In arresting Pelopidas, he presented himself unambiguously as an enemy of the Thebans. With this move he provoked an intervention of the Boeotian army, which he could expect in any case, but also gained the sympathy of the Athenians. When, receiving news of the Thebans' preparations for armed intervention, he sent delegates to Athens requesting an alliance, they were warmly welcomed. The Athenians agreed to form a coalition and sent help in the form of 30 triremes and a thousand men under the command of Autokles. The collaboration brought great success to both sides. Before the Athenians could reach Thessaly, Theban forces invaded, and after joining with local allies, the Thebans sought to settle the campaign in a battle. Yet their plan failed, as for unknown reasons the allies abandoned them. Alexan-

\footnotetext{
39 Xen. Hell. 7.1.28; Sordi 1958, 212-213.

40 Diod. 15.71.2-3; Plut. Pelop. 27; Heskel 1997, 40-43; Buckler 2003, 323-325.

41 On Alexander, see Sprawski 2006, 135-147; Boehm 2015, 209-251.

42 Xen. Hell. 7.1.28.
} 
der, meanwhile, joined forces with the Athenians and other allies. The isolated Thebans, lacking supplies, decided to retreat. Scourged by Alexander's cavalry, they were only able to avoid complete disaster by handing command to Epaminondas, who up until then had served in this campaign as a rank-and-file soldier. ${ }^{43}$

The Thebans did not give up their attempts to free the prisoners, and in spring 367 they again sent Epaminondas with major forces to Thessaly. Contrary to the hopes of the Thessalians, counting on Alexander's destruction, the Thebans were very cautious in their warfare, as shown by one of the stratagems described by Polyaenus. Plutarch also emphasises that Epaminondas delayed a direct attack, trying rather to intimidate his opponents and dissuade them from a battle. He puts the Theban commander's conduct down to his concern for the prisoners' lives, describing the tyrant's cruelties and the treacherousness of his character at length. However, Alexander proposed freeing the prisoners in exchange for peace. Epaminondas rejected these conditions, but agreed to a 30-day truce, and after the prisoners were freed immediately withdrew to Boeotia. Alexander enjoyed great success, escaping the confrontation with his most powerful opponent without losses. His position was strengthened by forming an alliance with Athens. In fact, the truce he concluded lasted almost three years. The Thebans must have been aware of the weakness of the Thessalian opposition to Alexander, and moreover, they involved themselves in negotiations to establish a general peace. ${ }^{44}$

In the course of the above events, the Athenians' position towards Alexander during Epaminondas' invasion is unclear. Sources say nothing about their military engagement. But it is hard to evaluate the situation because we know very little about the course of this campaign. Although it is unlikely that Alexander and the Athenians did not expect the Thebans' attack, we cannot rule out the possibility that the Athenians did not manage to take any actions to support their ally, especially as their fleet was involved in Iphikrates' manoeuvres against Amphipolis. It is also possible, however, that the mercenaries called up by Autokles stayed in Thessaly longer and left it only after the truce was made with Epaminondas. ${ }^{45}$ Leaving them in Thessaly for winter to be maintained by Alexander was also comfortable for the Athenians themselves. This situation seems to be confirmed

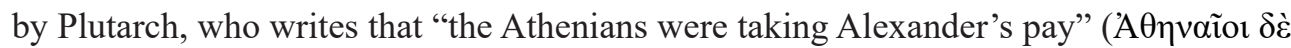

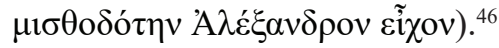

We therefore have reasons to believe that nothing happened in spring 367 to put a strain on the alliance formed several months earlier. Despite the lack of information about collaboration between Alexander and Athens after 368, it appears that the alliance was not formerly broken, as the Athenians only decided to demolish the stele with the text of this agreement in $361 / 360$. The lack of traces of collaboration is somewhat frustrating given the fact that we can discern events in the changing political situation that should have encouraged such cooperation from both sides. The first of these was the Athenians' loss of Oropos. In 366, when negotiations on the restoration of general peace ended in fiasco, it was controlled by a group of exiles probably with the support

43 Dem. 23.120; Diod. 15.71.3-4; Cloché 1923, 403-406; Buckler 2003, 325-327.

44 Diod. 15.75.2; Plut. Pelop. 29.1-3; 6; Polyaenus 2.3.13; Sordi 1958, 215; Roy 1994, 195-196. For the chronology, see Buckler 1980, 248-249; Stylianou 1998, 450-451.

45 See Cloché 1923, 406.

46 Plut. Pelop. 31.4. (tr. B. Perrin). 
of Themison, tyrant of nearby Eretria. Keen to win back this important region, the Athenians mobilised sizable forces, entrusting command to Chabrias. Before this, however, Theban forces commanded by Epaminondas reached Oropos. Facing such an opponent, Chabrias decided against fighting and withdrew his troops. By leaving Oropos in the hands of the Thebans, Chabrias hoped to be able to recover it through arbitration, but his hopes were dashed. This was a painful defeat for the Athenians. Xenophon mentions their great disappointment with the approach of their allies, none of whom came to their aid. ${ }^{47}$ It is worth noting here, however, that this is the only reference to the Athenians expecting help from their allies. We do not hear of them requesting it before the Battle of Naxos or during later battles with Alexander. ${ }^{48}$

The other issue that should have caused consternation on both sides was the expansion of the Boeotian fleet and the demonstration of its might made by Epaminondas in spring of 364, when he led the assembled warships to the Aegean Sea. The first success of the Thebans was a victorious confrontation with the Athenian fleet commanded by Laches, which tried to stop them. We do not know the details of this confrontation, but Epaminondas must have felt confident facing much more experienced opponents. It may be that Laches, seeing his rival's numerical advantage, withdrew without a fight. The Theban fleet continued its voyage without hindrance, securing gains in the form of an alliance with Rhodes, Chios and Byzantium. These successes made a big impression on the Athenians. Some twenty years later, Isocrates mentioned them when he wrote that the Thebans sent their warships to Byzantium as if their intention was to gain power both on land and at sea. We find a similar assessment of the Theban ambitions in Diodorus. Writing with the benefit of hindsight about Epaminondas' campaign, he argues that if he had lived longer the Thebans would certainly have gained hegemony on land as well as at sea. If Epaminondas aspired to domination at sea, his expedition was just the first step in this direction. He may have been interested only in weakening the Athenians' position by demonstrating that their hegemony could be challenged. Although his fleet did not inflict losses on the Athenians directly, its appearance might have caused a large amount of unrest on the Aegean Sea. Yet Epaminondas' expedition remained an isolated venture, as the Thebans did not continue his bold maritime policy. ${ }^{49}$

No information survives on Alexander's reaction to the expansion of the Boeotian fleet and Epaminondas' expedition. One can only assume that he cannot have been entirely indifferent to these events. According to Buckler, when Epaminondas set sail in early spring 364 he chose the northern route through the Malian Gulf. This route led through the calm waters of the Euboean Channel and allowed him to avoid Athenian outposts in Rhamnus. ${ }^{50}$ If the Boeotian fleet indeed chose the northern route, it sailed through the Malian Gulf along territories under Alexander's rule. Whatever the route taken by the Boeotian fleet in 364, the very fact of its expansion must have posed a threat

47 Xen. Hell. 7.4.1-2; Dem. 18. 99; Aesch. 2.164; 3.85; Diod. 15.76.1; Buckler 1980, 193-195.

48 Dreher 1995, 278-279.

49 Isocr. 5.53; Diod. 15.78. 4-79. 2; Plut. Phil. 14.1. On the maritime programme of Thebes, see Carrata Thomes 1952; Buckler 1980, 160-175; Buckler 1985, 13-15; Buckler 1998, 192-204; Heskel 1997, 131132, 140; Stylianou 1998, 494-496. Cf. Cawkwell 1972, 271; Ruzicka 1998, 60-69.

50 Diod. 15.79.1; Buckler 1980, 169-170, 255-259; Buckler 1985, 22; Heskel 1997, 64-65. According to Carrata Thomes (1952, 36-37), Epaminondas sailed into the Malian Gulf on his return journey. 
to the trade routes leading to Pagasae. In this situation, Alexander should have been interested in maintaining the alliance with Athens, especially given the plans to resume the struggle for control of the Thessalian cities. For the Athenians too, Alexander controlling the convenient port in Pagasae might have been an attractive partner. But we have no evidence to suggest their cooperation, although both sides were very active at this time. There is no doubt that the Athenians were concentrating on attempts to regain Amphipolis. From 365, Timotheus was in command, and although he did not conquer Amphipolis, he had major successes in occupying Pydna and Methone. He then took Samos and targeted the Hellespont region, where he conquered Sestos, before setting out to the Black Sea. In 364 he sailed into Chalkidiki, where he captured Potidaia and Torona. ${ }^{51}$ At this time, Alexander renewed the war with the opposition Thessalian cities. According to Diodorus, he achieved a series of victories, inflicting major losses on his opponents. He was therefore able to place his garrisons in Achaea Phthiotis and Magnesia. He thus brought under his control an entire band of coastline from the Malian Gulf to the mouth of the Pineios. His successes induced the Thessalian opponents to call on Thebes for help..$^{52}$

At the Thessalians' request, the Thebans decided to send Pelopidas with 7,000 soldiers. Yet the solar eclipse on 14 July 364 was seen as a bad omen, and resulted in the plans being abandoned. Pelopidas decided to set off for Thessaly only in the company of a group of volunteers and mercenaries. At the head of these forces and the Thessalians supporting him, he clashed with Alexander at Cynoscephalae. Alexander endured major losses in the battle, but thanks to Pelopidas' death he was able to keep his position. Probably in autumn the same year, the weakened Alexander again had to contend with the main Theban forces. This time he lost and had to agree to negotiations. In the end he made an agreement which left Pherae in his hands, but forced him to abandon the Thessalian cities occupied previously and Magnesia. He also had to hand over control of Achaea Phthiotis to the Boeotians and form an alliance with them. ${ }^{53}$

Sources tell us nothing about the Athenians' attitude to these events. Plutarch emphasises, however, that their relations with Alexander before Pelopidas' expedition were very good. The Athenians apparently erected a monument to him and took money from him. ${ }^{54}$ Unfortunately, we do not know why they left their ally without help. Perhaps it was just an effect of inability to react appropriately to a situation that demanded it. In the 360s, Athens' active policy encountered obstacles such as problems with collecting funds for financing campaigns and finding a sufficient number of experienced oarsmen to man their warships. ${ }^{55}$ It is also possible that Alexander was no longer attractive as an ally. His brutality in dealings with Thessalian cities might also have put the Athenians off engaging in his defence.

Forced to form an alliance with the Boeotians, Alexander had to make another reversal in his policy. In early summer 362, according to Xenophon, "great numbers of Thes-

51 For the chronology, see Buckler 1980, 255-259.

52 Diod. 15.80.1; Plut. Pelop. 31.1.

53 Diod. 15.80; 81.3; Strabo 9.5.6; Nepos, Pelop. 5.2-4; Plut. Pelop. 32-35; Westlake 1935, 144-145; Sordi 1958, 225; Boehm 2015, 239; Heskel 1997, 67; Sprawski 2006, 144-145.

54 Plut. Pelop. 31.4.

55 See Cawkwell 1984, 335-338; Rhodes 2012, 120-121. See also Gabrielsen 1994, 107-110. 


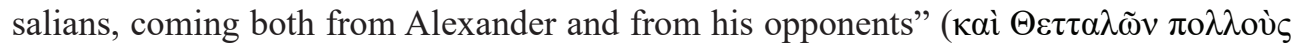

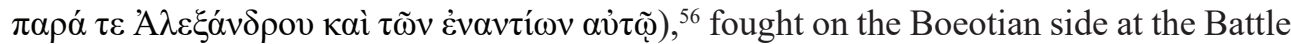
of Mantinea. Alexander must have openly opposed the Athenians, probably fulfilling the obligations of the agreement formed with Thebes.

Alexander's next step was to undertake a maritime campaign against the Athenian allies, which ultimately earned him the view expressed by Xenophon, who called him

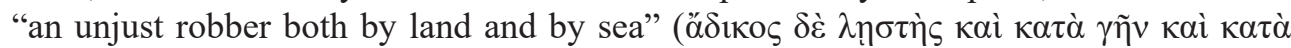
$\theta \alpha \dot{\lambda} \alpha \tau \tau \alpha \nu) .{ }^{57}$ Diodorus gave a similar verdict on his actions, writing that he sent pirate

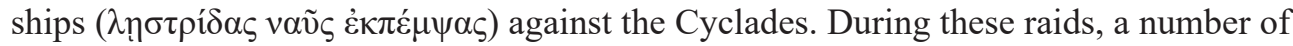
islands were attacked and many people were enslaved. Among these were the island of Tenos, whose fate is mentioned in a speech by the Athenian rhetorician Apollodorus. We know from this that the Athenians debated the problem of a series of misfortunes they had experienced, including Alexander's attack on Tenos, during the popular assembly that took place at the end of the month of Metageitnion, falling in August and September 362. Alexander's campaign must have taken place at the latest in the first half of August of that year. ${ }^{58}$

Buoyed by his successes to date and the lack of a decisive reaction from the Athenians, Alexander did not stop at pirate raids, but also undertook armed interventions on a considerably wider scale. In 361 he attacked the island of Peparethos, lying near to the coast of Magnesia. Encountering resistance from its main city, Alexander decided to mount a regular siege. We can therefore assume that his aim was not to sack the island, but to establish lasting control there. This time the Athenians made a decisive counterattack and sent a squadron of warships under the command of Leosthenes to help. ${ }^{59}$ Diodorus' account shows that thanks to the rapid response, the Athenians managed to entrap the Thessalian forces in Panormos. Alexander did not accept defeat, but he did not dare to attack the Athenians immediately. It is likely that he sought support at this time by sending letters to the mercenary leader Charidemus of Oreus, who later maintained that he had not received Alexander's envoys. We only know about this subject from a speech by Demosthenes, who presents Charidemus in a very unfavourable light, accusing him of constantly acting to Athens' detriment. The orator suggested that Char-

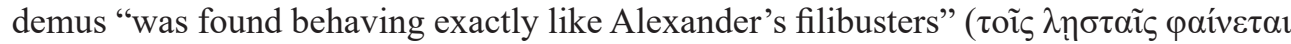

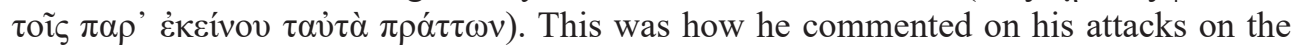
Athens-friendly cities of Krithote and Elaeus on the Chersonese. Yet there is no reason to suppose that he collaborated with Alexander. We cannot rule out, however, as Julia Heskel suggests, that Alexander managed to secure mercenaries from another source, emboldening him to mount another attack on Panormos. ${ }^{60}$

The details of the events that led to capturing Panormos were given by Polyaenus. According to his description, Alexander was able to contact his men at Panormos and send them the order to observe the Athenians' movements. They were supposed to in-

56 Xen. Hell. 7.5 .4 (tr. C. L. Brownson); Westlake 1935, 150-152.

57 Xen. Hell. 6.4 .35 (tr. C. L. Brownson).

58 [Dem.] 50.4; Diod. 15.95.1; Westlake 1935, 153; Sordi 1958, 223, note 4.

59 Diod. 15.95.1; Polyaen. 6.2.1; Heskel 1997, 69-70.

60 Dem. 23.162 (tr. A. T. Murray); Prittchett 1974, 85-86, 89; Kallet 1983, 249-250; Kelly 1990, 104 105; Heskel 1997, 69. 
form him by beacon signals if any Athenian ships left the port. The chance for an attack came when Leosthenes, the commander of the Athenian fleet, decided to send warships to Samos, Thasos and the Hellespont, presumably requesting support. Alexander's men sent a message from Panormos to Pagasae by beacon signals. The tyrant manned the shops and immediately set off for Peparethos. Leosthenes managed to save himself, but the furious Athenians put him on trial for treason, sentenced him to death and confiscated his property. The Athenians' indignation was understandable given the fact that Alexander had exploited his unexpected success in the sea battle and attacked Piraeus. Not encountering resistance, his ships sailed into the main port. Nobody suspected them of hostile intentions, and therefore Alexander's crew were not stopped by anyone when they left their vessels and set about plundering the deigma, the place where the transactions took place. The traders and bankers who were there became their victims. Before the commanders in Athens could be informed of the attack on the port, the aggressors had set sail with the plundered money. ${ }^{61}$

Alexander made good use of Athens' engagement on various fronts in 362. His attack on Tenos coincided with a call from Miltocythes with an offer to hand over Chersones in return for providing help against the Thracian king and with a call from Proconnes for help in the fight against Cyzicus. At the same time, the Athenians were alarmed by the news that the fleet carrying grain from Pontus to Piraeus had been stopped by Byzantium, Chalcedon and Cyzicus. For the next few seasons, the Athenians focused their attention on securing safe passage through the Hellespont of ships carrying grain to Piraeus. Meanwhile, from 364 Timotheus led operations on Chalkidiki against Olynthus. All these activities put the system of mobilisation of the Athenian fleet under strain, causing temporary problems, as shown in Apollodorus' speech. ${ }^{62}$

The actions taken by Alexander in this period did not pose a direct threat to Athens, but there is no doubt that they contributed to destabilising the situation on the Aegean Sea and affected Athens' authority and maritime trade. Seeking an effective solution to the problem, the Athenians began negotiations with Alexander's Thessalian enemies. As a result, in 360/361 the Athenians formed an alliance with the Thessalian League aimed against him, the resolutions of which were preserved on an inscription. The parties signed the agreement "forever," committing not to conclude a peace with Alexander without the agreement of the others. All allies of Athens became allies of the Thessalians. The Athenians also undertook to demolish the stele with the text of the alliance once formed with Alexander. But the very fact that the stele was still standing many months after the evident breaking of the alliance does not provide a basis for drawing far-reaching conclusions. As S. Bolmarcich showed, although the agreement recorded on a stele was no longer valid, it was usually left. The act of destruction of such a stele was unusual: "it occurs as a premeditated action, meant to make a powerful political and diplomatic statement." Such an act required use of the appropriate legal procedure and was preceded by discussion. ${ }^{63}$ Enshrining in the conditions of the agreement the decision to remove the stele with the treaty formed with Alexander was therefore a telling

61 Polyaen. 6.2.1. On deigma, see Bresson 2016, 310.

62 Cawkwell 1984, 335-342; Sealey 1993, 91.

63 Bolmarcich 2007, 483, 484-485 (where he refers to the clause of the demolition of the stelae with the agreement formed with Alexander). 
expression of the moods in Athens and the determination of the negotiating parties to oppose him.

The Athenians' alliance with the Thessalian League may have curbed Alexander's actions. In any case, the sources contain no information on further attacks by him. We also have no evidence confirming that the allies undertook joint initiatives. It is possible, as in the previous years, that the Athenians could not afford an armed intervention in Thessaly, and Alexander's death soon removed the reason for forming an alliance. At the same time, the Thessalians, seeking fruitful help, turned to Philip II, who was in conflict with Athens. The alliance between the Thessalian League and Athens therefore did not last long, and a direct consequence of it could only be reinforced ties between Alexander and the Thebans. ${ }^{64}$

It has been suggested that the Thebans' policy towards the Thessalians changed after Pelopidas' death. They may have reached an agreement with Alexander, who proved to be an attractive ally for them. According to this suggestion, the effect of these closer relations was his maritime campaign. M. Sordi notes that the incursions against the Cyclades could only have taken place thanks to Alexander's access to the neighbouring ports. In her view, these may have been the ports of the Theban allies in Argolis. At least initially, these raids were agreed with the Thebans and connected with the campaign in the Peloponnese. ${ }^{65}$ According to Carrata Thomes, Alexander's fleet may have consisted of some of the Boeotian warships provided to him and built on the initiative of Epaminondas. ${ }^{66}$ According to G. Kip, however, the Thebans agreed for Alexander to retake control over Magnesia as a reward for his participation in the Battle of Mantinea. Polyaenus suggests that during the Battle of Panormos he must have controlled at least its southern part. ${ }^{67}$ Indirect proof of the rapprochement between them can also be found in a reference by Xenophon, who notes that towards the end of his life the tyrant was ready to abandon his wife as well as Jason's daughter Thebe to unite with his predecessor's widow, who lived in Thebes at the time. If Jason's wife belonged to one of the influential families of Thebes, then perhaps this was an attempt on Alexander's part to bring about closer ties with this city. ${ }^{68}$

In the context of reflections on the Thebans' attitude to Alexander, the moment when he commenced his maritime campaign is important. If this happened after the Battle of Mantinea, his action can be treated as an attempt to become independent at a time when the Thebans' position had become weak. It has been suggested, however, that there is a link between the appearance of Alexander's fleet in the Cyclades and the anti-Athenian revolt that took place in Ioulis on the island of Keos. Connecting these events allows us to place the beginning of the maritime campaign to 363 , in the period just after the alli-

64 R\&O 44 with commentary; Westlake 1935, 154; Sordi 1958, 228-229, 232. Rogers (1932, 16, no. 1) associates the activity of the Thessalian League in the years 361-360 bronze coins with the legend ПET- $\Theta A$ $\Lambda \Omega N$. This issue shows that the League was able to undertake military actions financed from a joint fund. Cf. note 38 .

65 Sordi 1958, 222-223.

66 Carrata Thomes 1952, 43-44.

67 Kip 1910, 78-79.

68 Xen. Hell. 6.4.37; Westlake 1935, 152-155; Badian 1999, 111-112. 
ance with the Boeotians. ${ }^{69}$ If we accept this suggestion we must also acknowledge that Alexander's fleet was immediately ready for action. It is hard to imagine that Alexander would have undertaken the costly actions of expanding his fleet when the extent of his power had been drastically reduced. It is more likely that he maintained warships beforehand - maybe still those built by Jason. This in turn suggests that in the previous years the fleet was carrying out missions that allowed their upkeep to be funded and brought Alexander tangible benefits. These missions must have ended at the same time when he was forced to abandon the alliance with the Athenians. The conclusions that can be drawn from analysis of his policy do not indicate that he engaged in political actions using the fleet. If he maintained a usable fleet, therefore, perhaps he needed it for escorting trading ships and fighting off the threat of pirates. Such initiatives may have been financed by the Athenians, and ended at the moment when he formed an alliance with Thebes. If Alexander was cut off from the source of this income, this might explain the vehemence of his reaction.

\section{Jason's Sons}

In late 358 or early 357, Alexander was murdered by Jason's sons Lycophron and Tisophonus with the participation of Thebe, their sister and also the tyrant's wife. Diodorus mentions this in a very brief relation presenting the events taking place over the years from the death of Alexander Pherae to the rule of Alexander the Great. This abbreviated presentation causes difficulties in reconstructing the chronology of these events. But it seems that after the successful assassination the brothers were warmly received, extolled as tyrannicides. Later, however, they too would become tyrants. To gain power, they paid off and enticed mercenaries - no doubt the same ones who had previously been in Al-

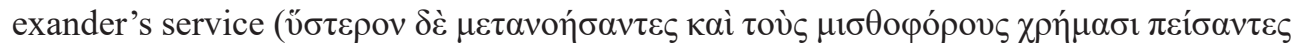
$\dot{\alpha} v \varepsilon \dot{\delta} \varepsilon 1 \xi \alpha v \dot{\varepsilon} \alpha v \tau o v ̀ \varsigma \tau v \rho \alpha ́ v v o v \varsigma) .{ }^{70}$ This presumably took place soon after the murder, still in 358 or at the beginning of 357 , because if they did so later, it would be difficult to find an answer to the question of who paid the mercenaries and to what end he maintained them. It is therefore more likely that after a short period of uncertainty the brothers bought off the mercenaries and assumed power in the city. In this context, numismatics provides interesting evidence. Like Alexander, Tisiphonus issued bronze coins with his name. Bronze coins were nothing new in Thessaly, but it is worth noting that they were mainly used in the local market, and were often used to pay soldiers. ${ }^{71}$ The low quality of production of the surviving examples of these coins has been noted, which might point to the haste with which they were issued. ${ }^{72}$ It is possible that this resulted from the need to quickly gather funds for paying the mercenaries.

69 Heskel 1997, 67-70. See also Duszyński 2020.

70 Diod. 16.14.1.

71 See Rogers 1932, 167, nos. 527-530. For the use of bronze coins for military payment, see Psoma 2009, 3-38; Sheedy 2015, 203-223.

72 Triton XV: 290, nos. 709-711. 
According to Diodorus, after Jason's sons assumed tyrannical rule, they were opposed by the Aleuadae from Larissa, who, without sufficient forces, called upon the Macedonian king Philip for help. The question of the chronology of Philip II's intervention in Thessaly has been discussed on numerous occasions. There seem to be serious grounds to conclude that the first of these took place just after Alexander's death, i.e. several years before he involved himself in fighting with the Phocians and brought about the abolition of tyranny in Pherae. It is most likely that Philip came at the behest of Larissa, which was alarmed by Jason's sons' assumption of control over Alexander's mercenaries, and de facto the creation of tyrannical rule in Pherae. Philip, like his elder brother earlier, probably intervened in defence of the Aleuadae from Larissa. Yet he was not willing to remove the tyrants from Pherae. His objective may have in fact been to alleviate the conflict in Thessaly and form personal ties with its leaders. This was the purpose of his two marriages with Thessalian women: Philinna from Larissa and, tellingly, Jason's niece Nicesipolis from Pherae. Although we do not know the date of these marriages, there are reasons to place them in this period. For Jason's sons, Nicesipolis' marriage was a diplomatic success that allowed them to consolidate their position. ${ }^{73}$

Genuine power after Alexander's death was probably assumed by the elder of the brothers, Tisiphonus. The scholia on Aristides' speeches contain a reference saying that it was he who sent the ships to support the Theban operation on Euboea. ${ }^{74}$ This was an intervention in an internal conflict that engulfed the island in 358/357 and gave the Thebans a pretext to take full control of the island. At least this was how the Athenians saw the events, responding remarkably decisively. They dispatched warships and land forces to the island, which after 30 days of fighting forced the Thebans to retreat. Euboea fell into the hands of the Athenians and their allies. ${ }^{75}$ By sending his fleet just after coming to power, Tisiphonus demonstrated his loyalty to the Thebans and determination to preserve the alliance that bound them with Alexander. This provides us with a final confirmation that the Pheraean fleet was still capable of undertaking offensive actions. We can therefore assume that in previous seasons it carried out missions justifying maintaining ships in battle readiness, despite the limited resources Alexander had at his disposal. At the beginning of his reign, therefore, Tisophonus had to find money not only to pay mercenaries, but also to meet the costs of the military expedition, unless these were borne by the Thebans. It is possible that the aforementioned issue of bronze coins was connected to these actions.

The reconstruction of events presented above suggests that the continuity of the alliance between the Boeotians and the Pheraeans was preserved. A different reconstruction seems to be demonstrated by Isocrates' letter to Jason's sons. The author points out the obstacles preventing him from accepting the invitation to settle alongside them and expresses the concern that the alliance formed with Athens would soon be broken

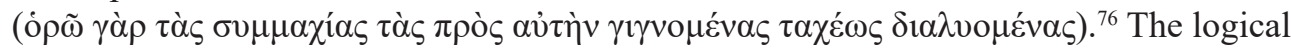

73 Satyrus ap. Athen. 13.567c; Tronson 1984, 121-122; Badian 1999, 112. Some prefer to date Philip's marriage with Nicesipolis after the Battle of Crocus Field and the overthrow of the tyranny in Pherae for example: Griffith 1979, 278; Worthington 2008, 64-65.

74 Scholia ad Aristid. Panathen. (ed. Dindorf, vol. III), p. 298.

75 Dem. 8.74; 18.74; Aeschin. 3.85; Diod. 16.7.2; Sealey 1993, 102-103.

76 Isocr. Ep. 6. 
conclusion to be drawn is that at the moment when the letter was written Pherae was in an alliance with Athens. Although it appeared fragile to the author, we do not know whether it was in fact ended. The key problem remains determining the date when the letter was sent. Since it contains warnings to the brothers to avoid the temptation to claim tyrannical rule, it must have been written before they did this. As we recall, in Diodorus' description, after Alexander's murder the brothers enjoyed renown as tyrannicides, yet later (vँ $\sigma \varepsilon \rho \circ v)$ they paid off mercenaries, murdered their opponents and took power by force. Westlake argues that the alliance with Athens was formed just after Alexander's murder, but survived only until tyrannical power was assumed, which was the reason why it was broken. Tisiphonus and his brothers concluded an alliance with Thebes at this time, which resulted in sending a fleet to Euboea. All these events must have taken place in the course of a few months, and at this time the alliance was twice reversed. ${ }^{77}$ It seems more likely that Pherae and Athens formed closer relations only in 354. Previously, against the backdrop of conflict in the Amphictyonic Council of Delphi, the Thessalian League's alliance with Athens was probably loosened. Following accusations from the Phocians of sacrilege, the Thessalians consistently supported the Thebans, demanding punishment of the guilty. After the outbreak of the Third Sacred War, the Thessalians sent their units to Phocis, but were routed in the Battle of Argolas in 354. Jason's sons decided to exploit this compromising defeat to regain leadership in Thessaly. They abandoned the alliance with the Thebans, who had found themselves in a difficult situation this year. By sending Pamenes with 5,000 hoplites to Asia, they lost their main attack force, which the Phocians exploited by occupying the eastern part of Boeotia with Orchomenos. At the same time, the Phocians apparently bribed the Thessalians so that the soldiers would withdraw. In these circumstances, Lycophron and Peitholaus made a bold move by forming an alliance with the Phocians, no doubt counting on their financial and military support. Presumably at this time an alliance with the Athenians was formed, which Isocrates mentions in his letter. His addressees must have been Lycophron and Peitholaus, as the eldest of the siblings, Tisiphonus, was probably dead. The warnings sent to them referred not to the possible development of events in Pherae, but to the competition for leadership in Thessaly. ${ }^{78}$

In the new political situation, the Thessalians opposed to Pherae and their allies again asked Philip II for help. After capturing Methone, he invaded Thessaly and began a war with Lycophron and the Phocians supporting him. After the first successes, he was defeated in two battles fought against the Phocian forces commanded by Onomarchus. ${ }^{79}$ Forced to retreat, Philip returned in spring 353, again mobilising the Thessalians to fight. His cavalry heavily outnumbered Onomarchus' forces, and pushed them into the sea. The description of the battle in Diodorus suggests that it took place on lowlands by the sea, which are identified as Crocus Plain, near to Almiros in the Pagasetic Gulf. ${ }^{80}$

Diodorus mentions that during the sea battle, numerous Athenian warships commanded by Chares appeared. Some of Onomarchus' soldiers tried to save themselves from the slaughter by swimming to them. According to Diodorus, the fleet sailed past

77 Westlake 1935, 164-165.

78 See Sordi 1958, 241-243; cf. Griffith 1979, 227-228.

79 Diod. 16.35.

80 Buckler 1989, 74-75. 


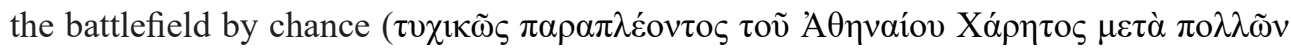
$\left.\tau \rho \imath \rho^{\prime} \omega v\right)$. Its target may have been Pagasae, which had possibly been designated as a rallying point for the army supporting the Pheraeans. ${ }^{81}$ If we accept this suggestion, we must also accept that the battle took place in a different place than the coalition partners expected, and perhaps this is why we do not hear of the participation of Pheraean warships in these events.

The Battle of Crocus Plain determined sealed Pherae's fate. Lycophron and Peitholaus, denied the allies' support, decided to surrender the city in exchange for permission for free passage together with 2,000 mercenaries with whom they joined the Phocians. They no doubt abandoned Pagasae, which fell into Philip's hands, at the same time. However, controversies surround the dating of the fall of Pagasae. It has been suggested that it might have fallen into Philip's hands before the battle. According to this version, Chares' fleet set sail with help for Pagasae, but did not make it in time and had to turn back. This is why the city is named as one of those to which Athenian aid did not arrive on time. ${ }^{82}$ N. G. L. Hammond, meanwhile, showed on the basis of Diodorus that it must have taken place immediately after the fall of Methone, in autumn 354. ${ }^{83}$

After leaving Pherae, for some time Lycophron and Peitholaus retained their mercenaries. In 352 they sent them to help the Phocian commander Phayllos, who, with the support of many allies, had conducted unsuccessful Boeotian campaigns. ${ }^{84}$ The same year, they sent to the Peloponnese a detachment of 150 soldiers as support for the Phocian infantry, which took part in Archidamos' campaign against Megapolis. ${ }^{85}$ Unfortunately, we do not know what happened to the warships stationed in the port. The exiled brothers still had enough money to pay their mercenaries. These funds might to a large part have been gained from the Phocians. It is also possible that they kept a few ships, which they maintained when carrying out tasks supporting the Athenian fleet. We know that in 373 the Athenians covered the costs of maintenance of the Boeotian ships supporting them. ${ }^{86}$ Even if in 353 the Athenians were able to cover the pay of the Pheraean sailors, loss of control of Pagasae meant not only losing the place where warships were stored and renovated, but also being cut off from the recruitment base for oarsmen. And yet we hear that at this time attracting oarsmen was a serious problem, which the Athenians has been struggling with for several years. ${ }^{87}$ In these conditions, maintaining the ships must have been a serious challenge for Lycophron and Peitholaus. The lack of further mentions of the Pheraean fleet therefore suggests that it ceased to exist.

Peitholaus, the youngest of Jason's sons, probably returned to Pherae for a short period. According to Diodorus, in 349/348, after his successes fighting against cities on the Chalkidiki peninsula, Philip II headed southwards and deposed Peitholaus from Pherae. We know nothing more about these events. This mention by Diodorus has aroused

81 Diod. 16.35.5; Buckler 1989, 74.

82 Dem. 4. 35; Beloch 1922, 268.

83 Diod. 16.31.6; Hammond 1937, 67. This proposal is based on an emendation appearing in the manuscript of Pagas to Pagasae, which is widely accepted.

84 Diod. 16.37.3; Buckler 1989, 86-87.

85 Diod. 16.39.3; Buckler 1989, 90-91.

86 Dem. 49.14; Carrata Thomes 1952, 17.

87 Cawkwell 1984, 337-338. 
a great deal of controversy, and some scholars see it as an error. Doubts have been raised regarding the possibility of Pherae breaking free of Philip II's rule in this year, or at least over whether Peitholaus really participated in these events. ${ }^{88}$ The dominant view, however, is that such a return cannot be ruled out. It is made more likely by the dissatisfaction that Philip II's policy was met with in Thessaly. In mid-349, Demosthenes stated that the Thessalians were demanding that the king hand over Pagasae and cease the fortification of Magnesia, and that they intended to take away his income from ports and markets ( $\dot{\omega} \varsigma$

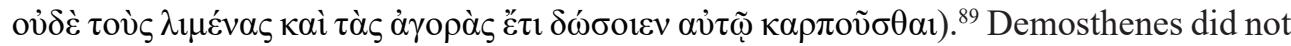
mention the problems with Pherae, which suggests that these might have emerged after he gave both speeches. It has been suggested that Philip really did withdraw his garrison from Pagasae, making it easier for Peitholaus to return..$^{90}$

Peitholaus' return might have taken place with the support of the Athenians, ${ }^{91}$ among whom for a certain time he was highly regarded. Information has survived that he and his elder brother Lycophron received Athenian citizenship, no doubt soon after leaving Pherae. As allies who in the battle with Philip lost their fatherland, they found refuge in Athens and encountered the sympathy of the Athenians, who made an appropriate decree on their citizenship at the popular assembly. After some time, the Athenians' attitude to the Pheraeans changed, and according to Apollodorus, Peitholaus was stripped of his citizenship by a court ruling. ${ }^{92}$ We do not hear of a similar decision regarding Lycophron, but it is likely that he was no longer alive then. We do not know how much time passed between these two decisions. The reasons for denying Lycophron privileges are unclear, but a trial was probably held over accusations that they were obtained through bribery. This is suggested by one sentence from the court speech against Peitholaus and his brother Lycophron preserved by Aristotle: "these men used to sell you when they were

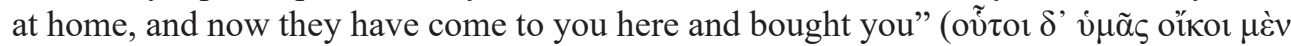

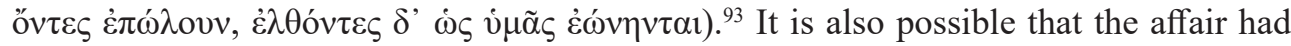
a political basis. In 346 the Athenians concluded the Peace of Philocrates with Philip, abandoning their Phocian allies. Perhaps they preferred to revise their position towards Jason's son on this occasion.

The maritime policy of the tyrants of Pherae was manifested in maintaining a fleet. For this to be possible, they needed the infrastructure for building and storing warships, financial means and wood. Control of Pagasae fulfilled the first condition. Electing Jason tagus and political control over the whole of Thessaly certainly helped to fulfil the second. He was given access to wood by an alliance with Amyntas, king of Macedon,

\footnotetext{
88 Sordi 1958, 358-361; Griffith 1979, 319-322.

89 Dem. 1.22, 2.11; Buckler 1989, 106-107; Badian 1999, 117-119.

90 Martin 1985, 95-99.

91 Westlake 1935,183 , note 3 .

92 [Dem] 59. 91.

93 Arist. Rhet. 1410a (tr. J. H. Freese); Sordi 1958, 359; Osborne 1981, 62-63; Badian 1999, 117, 119-120.
} 
concluded towards the end of his life. According to Xenophon, Jason was counting on obtaining wood from Macedon as a condition of development of the fleet. As long as there was an alliance between the Macedonian ruler and Pherae, supplies of this raw material were possible. The alliance ended in 369 with Alexander II's intervention against Alexander of Pherae. After this date, access to timber may have been more difficult.

There is no doubt that in 371 Jason had warships that he used in the Boeotian campaign. The next evidence of use of the Pheraean fleet only refers to Alexander's raids on the Cyclades in 362/361. We can only guess that this fleet was composed of ships built by Jason. If this was indeed the case, then Alexander must have footed the bill for maintaining this fleet for several years. Perhaps some of the costs were borne by the citizens of Pherae, especially if the ships were used to guarantee the safety of the port in Pagasae. Some of them were under Alexander's care, like the mercenary units he possessed. According to Carrata Thomes, Alexander himself might have expanded the fleet after forming an alliance with Thebes in 364. As an ally, he would have used the warships built on Epaminondas' command, whose upkeep was beyond the capabilities of the Boeotians. The use of Boeotian hulls solved the problem of access to the timber needed for building new ships. If, however, Alexander inherited sufficient ships from Jason, it would not have been necessary to use the Boeotian ones. Although the last information on Alexander's fleet refers to the year 361/360, we hear about it again just after his death. According to Westlake, when supporting the Thebans in 357, Peitholaus sent the same ships which helped Alexander to plunder the Cyclades. ${ }^{94}$

The above caveats notwithstanding, it seems that the core of Pherae's fleet was built in their greatest period, towards the end of Jason's reign, between 373 and 370. It may be a coincidence, but the period between the first and last mention of this fleet is no more than 16 years, which corresponds approximately to the average lifespan of a Greek trireme, estimated at 20 years. ${ }^{95}$

We do not have much data with which to estimate the size of the Pheraean fleet. What we do have available for the 4th century suggests that even the fleets of the largest powers sailing in the Aegean Sea were much smaller than those sent out in the 5th century. When the Athenians defeated the Spartans in 376 in the Battle of Naxos and regained domination at sea, Chabrias had 83 triremes under his command. ${ }^{96}$ Timotheus commanded 60 warships at Alyzia, ${ }^{97}$ whereas in 373 Iphikrates with great difficulty managed to assemble 70 ships to take to Korkyra. ${ }^{98}$ Cawkwell estimates that in the $360 \mathrm{~s}$ BCE, the Athenians maintained around 40 to 50 warships in active service. The average size of squadrons commanded by a strategos might have been 30 ships. It was with this number that Timotheus sailed against Samos in 365. ${ }^{99}$ Epaminondas, challenging Athenian hegemony at sea in 364, is said to have convinced the Boeotians to put up 100 warships. According to some scholars, however, there were no more than 40 built at the time, and it was with these forces that Epaminondas sailed on the Aegean Sea, without seeking

\footnotetext{
94 Westlake 1935, 113; Carrata Thomes 1952, 44.

95 Casson 1995, 90.

96 Diod. 15.34.5.

97 Xen. Hell. 5.4.63.

98 Xen. Hell. 6.2; Rutishauser 2012, 160.

99 Cawkwell 1984, 334-335.
} 
conflict with the main Athenian forces. ${ }^{100}$ The remaining states maintaining fleets on the Aegean Sea may have assembled much weaker forces. In the Battle of Naxos, the Spartan leader Pollis had 60 or 65 triremes under his command. ${ }^{101}$ The fleet assembled by the Spartans in 375 and 373 was of similar size. ${ }^{102}$ In this case, however, we hear that squadrons from 11 states participated in the expedition. By way of comparison, in 413, when the Spartans decided to assemble a fleet with their allies, it apparently amounted to 100 ships supplied by 12 states. Of this number, the Spartans and Boeotians provided 35 ships each and the Corinthians 15 . There were also 15 from the Locrians and Phocians jointly. Seven smaller states assembled a total of 20 ships, meaning that they sent two or three triremes each. ${ }^{103}$ Meanwhile, in 371 Cleombrotos seized 13 Theban triremes stationed in Creusis on the Gulf of Corinth. ${ }^{104}$

How common it was for small Aegean states to maintain fleets is a contentious issue. Brun referred to the phenomenon of Aegean cities having their own fleets in the 4th century, when the pressure from Athens was not as strong as it was in the previous century. An example is Peparethos, which not only maintained ships but even staged offensives against Halonnessos. Rutishauser, however, emphasises that we do not have information pointing unequivocally to the fact that the cities on the Cycladic islands had their own triremes. In his opinion, building and upkeeping several ships was an inefficient exercise considering the major costs involved. The example of Peparethos, however, shows that cities could maintain single ships. These were essential for protecting trading ships and ports from pirate attacks. Athens sent squadrons patrolling the sea, and sometimes offered help to their allies, but these were relatively modest forces that did not provide sufficient protection. Small cities were forced to look after their own security. ${ }^{105}$ In the sources we find information from the second half of the 5th and first half of the 4th century showing that small squadrons from two to five ships were stationed in key ports around the Euboea to secure trading routes, as was the case with the Spartan crew in Oreos. ${ }^{106}$ In 404 the Athenians were allowed to retain twelve warships to protect Piraeus. We also know that the fleet of Rhodes at the end of the 4th century numbered at least ten ships. ${ }^{107}$

What might the size of the Pheraean fleet have looked like in comparison? If Jason indeed planned to achieve supremacy at sea, he must have counted on assembling around a 100 warships. These, at least, are the numbers cited in the plans for the struggle for hegemony suggested by Epaminondas, as well as for the fleet of states opposing the Athenians in the Social War. ${ }^{108}$ But it seems doubtful that Jason was able to assemble such a large fleet, and indeed that he even had such ambitions. The example of Epaminondas' fleet, however, shows that in a short time a state without good access to timber,

100 Beloch 1922, 197, note 4; Cawkwell 1972, 271 (Epaminondas). Contra Buckler 1985, 13-15.

101 Xen. Hell. 5.4.61; Diod. 15.34.5.

102 Xen. Hell. 5.4.65, 6.2.3; Duszyński 2016, 67-69.

103 Thuc. 8.3.2.

104 Xen. Hell. 6.4.3.

105 Brun 1993, 179-181; Rutishauser 2012, 153. Cf. Dreher 1995, 29-30, 281.

106 Xen. Hell. 5.4.56. Cf. Moreno 2007, 129-130.

107 Xen. Hell. 2.2.20; Diod. 19.77.3.

108 Epaminondas: Diod. 15.78.4, 79.1-2. The Social War: Diod. 16.21.2. 
an excessive amount of money or any great seafaring traditions was able to put together a significant fleet. If the Boeotians did this, then Jason too might have conducted a similar programme. When he set off for Boeotia in 371, he must certainly have had more ships at his disposal than those necessary for protecting the port in Pagasae.

The warships built by Jason were seized by Alexander and used for the attacks on the Cyclades. ${ }^{109}$ According to Cawkwell, Alexander's fleet, like Philip II's, was not a large one. ${ }^{110}$ Unfortunately, we know little about the size of the Macedonian fleet during Philip II's rule. In 351 it was so small that according to Demosthenes a squadron of just ten triremes was sufficient to deal with it. Griffith maintains that "his effective naval strength still did not exceed about twenty triremes altogether." 111 During the siege of Panormos, the three ships sent back by the Athenians gave Alexander enough of an advantage to mount an attack. During this attack, he took control of five Athenian warships and one from Peparethos. Before the battle, therefore, his opponent's fleet consisted of at least nine ships. Alexander may therefore have had a similarly sized fleet, since he did not opt for a confrontation immediately. It may be that he preferred not to engage all his powers to avoid leaving Pagasae without protection. With this information in mind, as well as data about the size of the forces assembled by other Greek states, we can assume that Alexander's maritime forces may have numbered around 20 warships. This was a fleet that was able to provide Pagasae with effective protection, take part in the escort of trading ships, and possibly involve itself in pirate attacks. ${ }^{112}$ Alexander could make raids on the Cyclades with smaller forces, without forcing the Athenians to make more decisive steps. Small squadrons were enough for achieving the objective, and their maintenance costs did not exceed his current possibilities. We know that such raids, perhaps also from Pagasae, were made by Philip II's fleet towards the end of the 350s, demanding a ransom on the ships leaving Cape Gerastos, or attacking Lemnos and Imbros, and even the Attica coast near to Marathon. ${ }^{113}$ This was too small a fleet to join the competition for domination at sea, but Alexander did not really display such ambitions.

In a declaration quoted by Xenophon, Jason argued that Thessaly united under his leadership would be able to build and man more warships than the Athenians could. $\mathrm{He}$ also announced that he would be unwilling to form an alliance with them, although they were ready to do so. Xenophon seems to present Jason as if he indeed challenged the Athenians to a competition for dominion at sea. In the source evidence, however, it is hard to find confirmation of this theory.

Analysis of the relations between Pherae and Athens over around three decades leads to the conclusion that neither state was particularly concerned about their mutual relations. After Jason's death, only in 367 did Alexander bring about an alliance, which resulted in him receiving military aid. Throughout the entire period, this is the only attested example of an Athenian intervention in Thessaly. We also have no confirmation that the two parties worked together in subsequent years, despite the emergence of various

109 Westlake $(1935,112-113)$ was sceptical about the size of Jason's fleet.

110 Cawkwell 1981, 48, note 32.

111 Dem. 4.22; Polyaenus 4.2.22; Griffith 1979, 311-312; Müller 2020, 233-234.

112 For more on the subject of escorts (phylake) for trading ships provided for a fee by the Athenians, see Dem. 8.24-25; Gabrielsen 2001, 233

113 Dem. 4.34; Griffith 1979, 311. 
threats to both their positions. Consequently, Alexander was forced to form an alliance with Thebes, becoming an extremely troublesome enemy of Athens. To halt his maritime expeditions, the Athenians formed an alliance with the Thessalian League, yet this did not last too long. In 354 Jason's sons united with the Phocians, who were supported by the Athenians. We do not hear of any direct collaboration between them, but the tyrants expelled from Pherae found refuge in Athens. This alone might give us the impression that Pherae did not play a particularly important role in Athenian politics. In the 360 s and 350s, an alliance with its leaders was mainly useful for counteracting Theban influences. Yet the Athenians did not demonstrate any particular engagement in this region. In the case of the Pheraean tyrants, paradoxically we have more evidence of their cooperation with the Thebans, who, after all, were instrumental in the collapse of Alexander's position in Thessaly in 364. His conflict with Thebes was short-lived, however. Armed help was given to Thebes by Jason in 371, Polyphron in 369, Alexander in 362 and Peitholaus in 357. To this we can also add the Pheraeans' participation in battles with the Phocians on the Theban side in 354.

We can get a slightly different picture of the mutual relations if we concentrate on the Pheraean rulers' contacts with Athens. Jason, who declined to form an alliance, visited the city to take part in the trial of Timotheus. Alexander, having formed an alliance, enjoyed such acclaim among the Athenians that they erected a monument to him. Finally, Lycophron and Peitholaus, stripped of power and exiled from Pherae, were honoured by being awarded Athenian citizenship. These examples seem to demonstrate that the Pheraean leaders' personal relations with Athens were much more intensive than analysis of the political relations between them might suggest. Perhaps the reasons for this state of affairs should be sought in their business relations, suggesting that it would be useful to analyse the evidence referring to sea trading between Pagasae and Piraeus and the role the Pheraean tyrants played in it. These issues will be the subject of a separate paper. ${ }^{114}$

ABBREVIATIONS

R\&O - P. J. Rhodes, R. Osborne (eds.), Greek Historical Inscriptions, 404-323 B. C., Oxford 2003.

Triton XV - Triton XV: The BCD Collection of the Coinage of Thessaly, Classical Numismatic Group, January 3, 2012.

114 Cf. Sprawski 2020. 


\section{BIBLIOGRAPHY}

Badian, E. (1999), Philip II and the Last of the Thessalians, in: Ancient Macedonia 6, Thessaloniki: $109-122$.

Beloch, K. J. (1922), Griechische Geschichte III.1, Berlin-Leipzig.

Boehm, R. A. (2015), Alexander, "Whose Courage Was Great": Cult, Power, and Commemoration in Classical and Hellenistic Thessaly, Class. Antiq. 34: 209-251.

Bolmarcich, S. (2007), The Afterlife of a Treaty, CQ 57: 477-489.

Bresson, A. (2016), The Making of the Ancient Greek Economy: Institutions, Markets, and Growth in the City-states, Princeton.

Brun, P. (1993), La faiblesse insulaire: histoire d'un topos, ZPE 99: 163-183.

Buckler, J. (1980), The Theban Hegemony, 371-362 BC, Cambridge, MA-London.

Buckler, J. (1985), Boiotian Aulis and Greek Naval Bases, in: New Aspects of Naval History, Baltimore: $13-25$.

Buckler, J. (1989), Philip II and the Sacred War, Leiden-New York.

Buckler, J. (1998), Epaminondas and the New Inscription from Knidos, Mnemosyne 51: 192-204.

Buckler, J. (2003), Aegean Greece in the Fourth Century BC, Leiden-Boston.

Cargill, J. (1981), The Second Athenian League: Empire or Free Alliance?, Berkeley-Los AngelesLondon.

Carrata Thomes, F. C. (1952), Egemonia beotica e potenza martima nella politica di Epaminonda, Torino.

Cartledge, P. (1989), Agesilaos an the Crisis of Sparta, London.

Casson, L. (1995), Ships and Seamanship in the Ancient World, Baltimore-London.

Cawkwell, G. (1972), Epaminondas and Thebes, $C Q$ n. s. 22: 254-278.

Cawkwell, G. (1981), Notes on the Failure of the Second Athenian Confederacy, JHS 101: 40-55.

Cawkwell, G. (1984), Athenian Naval Power in the Fourth Century, CQ n. s. 34: 334-345.

Cloché, P. (1923), La politique étrangère d'Athènes de 371 à 361 avant J.-C., RBPH 3: 399-418.

Cloché, P. (1935), La politique étrangère d'Athènes de 404 à 338 avant Jésus-Christ, Paris.

Constantakopoulou, Ch. (2007), The Dance of the Islands: Insularity, Networks, the Athenian Empire, and the Aegean World, Oxford.

Dreher, M. (1995), Hegemon und Symmachoi. Untersuchungen zum Zweiten Athenischen Seebund, Berlin.

Duszyński, W. (2016), Sparta, its fleet, and the Aegean Islands in 387-375, Electrum 23: 65-76.

Duszyński, W. (2020), Athenian 'imperialism' in the Aegean Sea in the 4th c. BCE: The Case of Keos, Electrum 27: 117-130.

Gabrielsen, V. (1994), Financing the Athenian Fleet: Public Taxation and Social Relations, Baltimore.

Gabrielsen, V. (2001), Economic Activity, Maritime Trade and Piracy in the Hellenistic Aegean, REA 103: 219-240.

Grey, V. (1989), The Character of Xenophon's Hellenica, Baltimore.

Griffith, G. T. (1979), Part Two, in: N. G. L. Hammond, G. T. Griffith, A History of Macedonia, vol. II, Oxford.

Hammond, N. G. L. (1937), Diodorus' Narrative of the Sacred War, JHS 57: 44-77.

Heskel, J. (1997), North Aegean Wars, 371-360 BC, Stuttgart.

Kallet, L. (1983), Iphikrates, Timotheos, and Athens, 371-360 B.C., GRBS 24: 239-252.

Kelly, D. (1990), Charidemos's Citizenship: The Problem of "IG" ii ${ }^{2} 207$, ZPE 83: 96-109.

Kip, G. (1910), Thessalische Studien, Halle.

Larsen, J. A. O. (1960), A New Interpretation of the Thessalian Confederacy, CPh 55: 229-247.

Mandel, J. (1980), Jason: The Tyrant of Pherae, Tagus of Thessaly, as Reflected in Ancient Sources and Modern Literature. The Image of the "New Tyrant," RSA 10: 47-77. 
Martin, T. R. (1985), Sovereignty and Coinage in Classical Greece, Princeton.

Mitchell, F. W. (1984), The Rasura of IG II ${ }^{2}$ 43: Jason, the Pheraian demos and the Athenian League, Ancient World 9: 39-58.

Moreno, A. (2007), Feeding the Democracy: The Athenian Grain Supply in the Fifth and Fourth Century $B C$, Oxford.

Müller, S. (2020), Fleet, in: W. Heckel, J. Heinrichs, S. Müller, F. Pownall, Lexicon of Argead Makedonia, Berlin: 233-235.

Osborne, M. J. (1981), Naturalization in Athens, vol. 3, Brussel.

Prittchett, W. K. (1974), The Greek State at War, part II, Berkeley.

Psoma, S. (2009), Tas sitarchias kai tous misthous ([Arist.], Oec. 1351b): Bronze Currencies and CashAllowences in Mainland Greece, Thrace and the Kingdom of Macedonia, Revue belge de numismatique et de sigillographie 155: 3-38.

Rhodes, P. J. (2012), The Alleged Failure of Athens in the Fourth Century, Electrum 19: 111-129.

Rogers, E. (1932), The Copper Coinage of Thessaly, London.

Roy, J. (1994), Thebes in the 360s, $C A H^{2}$, vol. 6, Cambridge: 187-208.

Rutishauser, B. (2012), Athens and the Cyclades. Economic Strategies 540-314 BC, Oxford.

Ruzicka, S. (1998), Epaminondas and the Genesis of the Social War, CPh 93: 60-69.

Sealey, R. (1993), Demosthenes and His Time: A Study in Defeat, New York-Oxford.

Sheedy, K. A. (2015), The Emergency Coinage of Timotheus (364-362 BC), in: U. Wartenberg, M. Amandry (eds.), KAIPOE: Contributions to Numismatics in Honor of Basil Demetriadi, New York: 203-223.

Sordi, M. (1958), La lega tessala fino ad Alessandro Magno, Roma.

Sprawski, S. (1999), Jason of Pherae: Study on History of Thessaly in years 431-370 BC, Kraków.

Sprawski, S. (2004), Were Lycophron and Jason Tyrants of Pherae?: Xenophon on the History of Thessaly, in: J. Tuplin (ed.), Xenophon and His World, Stuttgart: 437-452.

Sprawski, S. (2006), Alexander of Pherae: Infelix Tyrant, in: S. Lewis (ed.), Ancient Tyranny, Edinburgh: $135-147$.

Sprawski, S. (2020), Merchants of Pherae. The Role of Maritime Trade in Relations Between the Thessalian Tyrants and Athens in the 4th Century B.C. (forthcoming).

Stylianou, P. J. (1998), A Historical Commentary on Diodorus Siculus Book 15, Oxford.

Tronson, A. (1984), Satyrus the Peripatetic and the Marriages of Philip II, JHS 104: 116-126.

Tuplin, Ch. (1993), The Failings of Empire, a Reading of Xenophon Hellenica 2.3.11-7.5.27, Stuttgart.

Underhill, G. E. (1900), A Commentary on the Hellenica of Xenophon, Oxford.

Westlake, H. D. (1935), Thessaly in the Fourth Century BC, London.

Wilcken, U. (1924), Zu Iason von Pherai, Hermes 59: 123-127.

Worthington, I. (2008), Philip of Macedonia, New Haven-London. 